\title{
EFFECTS OF VITAMIN C SUPPLEMENTATION ON ACUTE PHASE CHAGAS DISEASE IN EXPERIMENTALLY INFECTED MICE WITH Trypanosoma cruzi QM1 STRAIN
}

\author{
Ricardo Guimarães MARIM(1), Alex Silva de GUSMÃo(1), Roberto Esteves Pires CASTANHO(1), Rafael DEMINICE(3), \\ Altino Luiz Silva THEREZO(2), Alceu Afonso JORDÃo JÚNIOR(3) \& Luciamare Perinetti Alves MARTINS(1)
}

\begin{abstract}
SUMMARY
The tissue changes that occur in Chagas disease are related to the degree of oxidative stress and antioxidant capacity of affected tissue. Studies with vitamin C supplementation did not develop oxidative damage caused by Chagas disease in the host, but other studies cite the use of peroxiredoxins ascorbate - dependent on T. cruzi to offer protection against immune reaction. Based on these propositions, thirty "Swiss" mice were infected with T. cruzi QM1 strain and treated with two different vitamin C doses in order to study the parasitemia evolution, histopathological changes and lipid peroxidation biomarkers during the acute phase of Chagas disease. The results showed that the parasite clearance was greater in animals fed with vitamin $\mathrm{C}$ overdose. There were no significant differences regarding the biomarkers of lipid peroxidation and inflammatory process or the increase of myocardium in animals treated with the recommended dosage. The largest amount of parasite growth towards the end of the acute phase suggests the benefit of high doses of vitamin $\mathrm{C}$ for trypomastigotes. The supplementation doesn't influence the production of free radicals or the number of amastigote nests in the acute phase of Chagas disease.
\end{abstract}

KEYWORDS: Lipid peroxidation biomarkers; Chagas disease; Parasitemia; Inflammatory process; T. cruzi; Ascorbic acid.

\section{INTRODUCTION}

In Brazil, approximately three million individuals are infected by Trypanosoma cruzi, with a predominance of chronic cases resulting from past infections. However, in recent years the occurrence of acute Chagas disease has been observed in states of Bahia, Ceara, Piaui, Sao Paulo and Santa Catarina, with a higher frequency of cases and outbreaks in some states of the Amazon Region ${ }^{6}$.

In Chagas disease, it is observed that much of the damage to the host is caused by excess free radical production in tissues infected by T. cruzi. The reactive oxygen in the species metabolism (ROS) can damage any cell component, but the ones most affected are the cell membranes. In order to combat free radicals, aerobic biological systems use two mechanisms, one of which works with compounds such as reduced glutathione (GSH), superoxide dismutase (SOD), catalase, glutathione peroxidase (GSH-Px) and vitamin $\mathrm{E}$, which has the ability to neutralize ROS before they cause tissue damage. The other mechanism is performed by ascorbic acid, glutathione reductase (GSH-Rd) and GSH-Px, which repair the damage caused by free radicals, reversing membrane lipid peroxidation? ${ }^{9}$

The thiobarbituric acid reactive substances (TBARS) are compounds produced after membrane lipid peroxidation, and protein carbonyl is an oxidation product of cellular proteins. Both oxidative stress products are caused by Chagas disease. MAÇAO et al. ${ }^{12}$ revealed reduced levels of TBARS and protein carbonyl in patients with Chagas cardiomyopathy who received supplemental vitamin $\mathrm{C}$ and $\mathrm{E}$, showing a strong indication that these non-enzymatic antioxidants are effective in neutralizing the oxidative insult caused by Chagas disease.

Recent studies have shown that some parasites can decrease ascorbate-dependent antioxidative enzymes using the ascorbic acid present in infected tissues, and can therefore protect themselves from the oxidizing action of ROS and reactive nitrogen species (RNS) produced by host inflammatory cells ${ }^{11,14}$. In Saccharomyces cerevisiae, Plasmodium falciparum and T. cruzi peroxiredoxines (prx) type 1-Cys become active in peroxide detoxification when reduced by ascorbic acid. T. cruzi is lacking in catalase, superoxide dismutase and glutathione peroxidase selenocysteine-dependent and therefore depends on prx to decompose peroxides produced by host macrophages ${ }^{11,14}$.

Based on these suggestions we propose the respective study in mice experimentally infected with $T$. cruzi QM1 strain in the acute phase of Chagas disease.

(1) Department of Parasitology of Marília Medical School (FAMEMA). Rua Dona Maria Feres 165. 17519-070 Marília, São Paulo, Brazil.

(2) Department of Pathology of Marília Medical School (FAMEMA). Av. Monte Carmelo 800. 17519-030 Marília, São Paulo, Brazil.

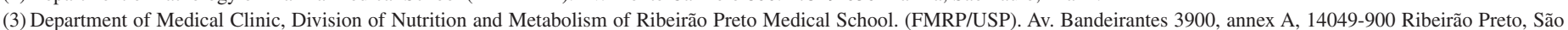
Paulo, Brazil.

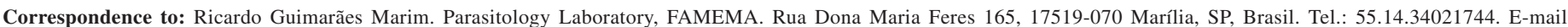
ricardo_marim@yahoo.com.br. 


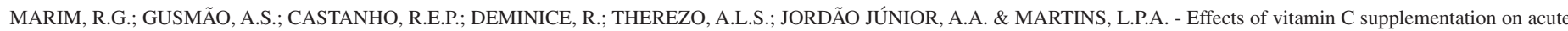
phase Chagas disease in experimentally infected mice with Trypanosoma cruzi QM1 strain. Rev. Inst. Med. Trop. Sao Paulo, 54(6): 319-23, 2012.

\section{MATERIALS AND METHODS}

1. Infection of mice: Thirty "Swiss" male mice, each 20 days old were intraperitoneally infected with $5.0 \times 10^{4}$ trypomastigotes of $T$. cruzi QM1 strain, characterized by MARTINS et al. ${ }^{13}$, using blood from other mice previously infected. Separated at random, three groups of 10 mice each were designated $\mathrm{R}, \mathrm{S}, \mathrm{P}$. The Recommended group (R) received the recommended dose of vitamin $\mathrm{C}$ per gram of weight, the Overdose group (S) received an overdose of vitamin $\mathrm{C}$ per gram of weight and the Placebo group $(\mathrm{P})$ received mineral water. The animals were kept in individual cages to facilitate handling and they were fed with Nuvilab CR-1® and water ad libitum.

2. Calculation of the vitamin $\mathbf{C}$ dose and treatment: Considering that the recommended daily dose of vitamin $\mathrm{C}$ for a man of 70,000 $\mathrm{g}$ is $60 \mathrm{mg}^{4,18}$, which results in approximately $8.6 \times 10^{-4} \mathrm{mg}$ of vitamin C per gram of weight, a D60 dose of vitamin C equal to $8.6 \times 10^{-4} \mathrm{mg} / \mathrm{g}$, dissolved in $10 \mu \mathrm{L}$ of mineral water was orally given to group $\mathrm{R}$ daily. Since various brands available for sale provide a dose of $500 \mathrm{mg}$ of vitamin C daily for a man of 70,000 g, which results in approximately $7.14 \times 10^{-3} \mathrm{mg}$ of vitamin C per gram of weight; a dose of vitamin C equal to $7.14 \times 10^{-3} \mathrm{mg} / \mathrm{g}$, dissolved in $10 \mu \mathrm{L}$ of mineral water was administered orally to group S D500 on a daily basis. Group P received $10 \mu \mathrm{L}$ of mineral water daily. Groups R, S and P received this treatment for 60 days. Each morning, all mice were treated and orally received $10 \mu \mathrm{L}$ of vitamin C D60, D500 or mineral water using a Gilson automatic pipette.

The treatment form, care and euthanasia of mice was in accordance with Cobea rules ${ }^{20}$. This study was approved by the Ethics Committee of the Faculty of Medicine of Marília (FAMEMA), protocol nº 133/10.

3. Study of parasitemia: During 60 days the parasitemia of each mouse from groups $\mathrm{R}, \mathrm{S}$ and $\mathrm{P}$ was determined twice a week following the BRENER ${ }^{3}$ method, starting on the $7^{\text {th }}$ day post- infection, and totaling 10 counts for each animal.

4. Histopathological study: For histopathological analysis a fragment of heart, colon and skeletal muscle tissue taken from the thigh of all mice of groups $\mathrm{R}, \mathrm{S}$ and $\mathrm{P}$ was collected on the $60^{\text {th }}$ day post- infection. The tissues were embedded in paraffin and $5 \mu \mathrm{m}$ sections were stained with hematoxylin-eosin and examined under a light microscope with 400 times magnification. For each fragment five sequential histological sections were performed, which were analyzed and graded for inflammation process and amastigotes nests, a total of 10 high magnification fields were performed for each type of tissue.

A semiquantitative scale from zero to three was used to grade the inflammatory process, amastigote nests and necrosis. "Zero" was considered as - the absence of inflammation, necrosis and amastigote nests, "one" - mild inflammation, and rare amastigote nests and necrosis, "two" - moderate inflammation, moderate number of amastigote nests and necrosis, and "three" - intense inflammation, frequent amastigote nests and necrosis.

5. Biochemical analysis: Blood was collected by cardiac puncture into heparin, centrifuged at $1000 \mathrm{~g}$ and $200 \mu \mathrm{L}$ plasma portion, and was immediately acidified with $800 \mu \mathrm{L}$ of $5 \%$ trichloroacetic acid for subsequent ascorbic acid determination. Plasma and homogenate were stored at $-80^{\circ} \mathrm{C}$. One fragment of heart muscle was immediately frozen in liquid nitrogen and subsequently stored at $-80^{\circ} \mathrm{C}$.

Thiobarbituric acid reactive substances (TBARS), a lipid peroxidation biomarker, were placed in plasma and heart muscle using a method adapted from COSTA et al. (2006) $)^{5}$. A portion of homogenated plasma or muscle $(100 \mu \mathrm{L})$ was mixed with $1 \mathrm{~mL}$ of a solution containing $15 \%$ $(\mathrm{w} / \mathrm{v})$ trichloroacetic acid, $0.38 \%(\mathrm{w} / \mathrm{v})$ thiobarbituric acid and $0.25 \mathrm{~mol} / \mathrm{L}$ of hydrochloric acid $(\mathrm{HCl})$. The mixture was heated at $100{ }^{\circ} \mathrm{C}$ for 40 minutes, and the supernatant was read at $535 \mathrm{~nm}$. Total concentration of TBARS was determined using the absorbance difference between samples and the standard solution of MDA.

Total peroxides, also a lipid peroxidation biomarker, were determined using the FOX method in cardiac muscle and plasma, as described by SÖDERGREN et al. $(1998)^{19}$. A solution of $100 \mu \mathrm{mol} / \mathrm{L}$ xylenol orange, $4 \mathrm{mmol} / \mathrm{L}$ butylated hydroxytoluene, $25 \mathrm{mmol} / \mathrm{L}$ sulfuric acid and $250 \mu \mathrm{mol} / \mathrm{L}$ ammonium ferrous sulfate in a HPLC grade methanol:water (9:1 v/v) was added to $100 \mu \mathrm{L}$ of plasma or muscle homogenate. The mixture was incubated for $30 \mathrm{~min}$ in darkness and at room temperature. Absorbance of the supernatant was measured at $560 \mathrm{~nm}$. Total peroxides in muscle and plasma were determined comparing them with the standard $\mathrm{H}_{2} \mathrm{O}_{2}$ curve.

The ascorbic acid concentration in plasma and heart muscle was determined according to $\operatorname{BESSEY}(1960)^{2}$. $100 \mu \mathrm{L}$ of solution containing 2,4-dinitrophenylhydrazine (2\%), thiourea (5\%) and copper sulphate $(0.6 \%)$ in sulfuric acid $(25 \%)$ was added to $300 \mu \mathrm{L}$ of acidified plasma. After four hours incubation in a $37{ }^{\circ} \mathrm{C}$ water bath, $200 \mu \mathrm{L}$ of sulfuric acid $(65 \%)$ was added. The 20 min reaction was performed at room temperature and the reading was performed at $520 \mathrm{~nm}$ in a spectrophotometer (Spectramax M5, Molecular Device), and compared to a standard ascorbic acid curve.

Statistical analysis: The results of the biochemical analysis were analyzed by descriptive statistical methods and statistical inference using the Student's t test and Fisher. The significance level used was 0.05. In order to analyze the histopathologic, descriptive data analysis, the following tests were used: Kruskal-Wallis test (ANOVA non-parametric) with post-test. Significance level was $5 \%$.

\section{RESULTS}

1. Study of parasitemia: Figure 1 shows that all groups had parasitemia on the $7^{\text {th }}$ day post-infection, and it appeared larger in group $\mathrm{S}$ than in groups $\mathrm{R}$ and $\mathrm{P}$, with statistically significant results. However, from the $13^{\text {th }}$ to the $40^{\text {th }}$ day there was an increase observed in groups $\mathrm{P}$ and $\mathrm{R}$, with more significant results on the $13^{\text {th }}$ and $16^{\text {th }}$ days than in group $\mathrm{S}$. However, at the end of the acute phase, group $\mathrm{S}$ showed a tendency to stabilize the parasitemia in higher values than in groups $\mathrm{R}$ and $\mathrm{P}$. It was observed that on the $50^{\text {th }}$ day group $\mathrm{P}$ showed lower parasitemia than groups $\mathrm{R}$ and $\mathrm{S}$ with a significant difference. An isolated analysis of the groups $\mathrm{R}$ and $\mathrm{P}$ showed a statistically significant difference only on day $50^{\text {th }}$ with higher parasitemia in group $\mathrm{R}$.

2. Histopathological analysis: Table 1 shows that the three groups showed inflammation in all tissues examined, although at a lesser intensity in the heart muscle. Group R showed a stronger inflammatory process in 


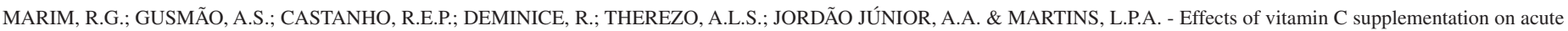
phase Chagas disease in experimentally infected mice with Trypanosoma cruzi QM1 strain. Rev. Inst. Med. Trop. Sao Paulo, 54(6): 319-23, 2012.

Table 1

Histopathological analysis in cardiac muscle, skeletal muscle and colon tissue during the acute phase of experimental infection by T. cruzi QM1 strain in mice treated with two different doses of vitamin $\mathrm{C}$ and placebo

\begin{tabular}{|c|c|c|c|c|c|c|c|}
\hline \multirow{2}{*}{ Groups } & \multicolumn{2}{|c|}{ Cardiac Muscle } & \multicolumn{3}{|c|}{ Skeletal Muscle } & \multicolumn{2}{|c|}{ Colon } \\
\hline & Inflammation & Amastigote & Inflammation & Amastigote & Necrosis & Inflammation & Amastigote \\
\hline $\mathrm{P}$ & 0.22 & 0.00 & 1.00 & 1.00 & 0.56 & 0.89 & 0.89 \\
\hline $\mathrm{R}$ & 0.78 & 0.00 & 1.56 & 1.22 & 0.89 & 0.56 & 1.33 \\
\hline S & 0.30 & 0.00 & 1.50 & 1.00 & 1.50 & 1.00 & 1.30 \\
\hline
\end{tabular}

$\mathrm{P}=$ animals treated with $10 \mu \mathrm{L}$ of mineral water; $\mathrm{R}=$ animals treated with $\mathrm{D} 60$ dose of vitamin $\mathrm{C}$ equal to $8.6 \times 10^{-4} \mathrm{mg} / \mathrm{g} ; \mathrm{S}=$ animals treated with D500 dose of vitamin $\mathrm{C}$ equal to $7.14 \times 10^{-3} \mathrm{mg} / \mathrm{g}$.

Parasitemia Curve

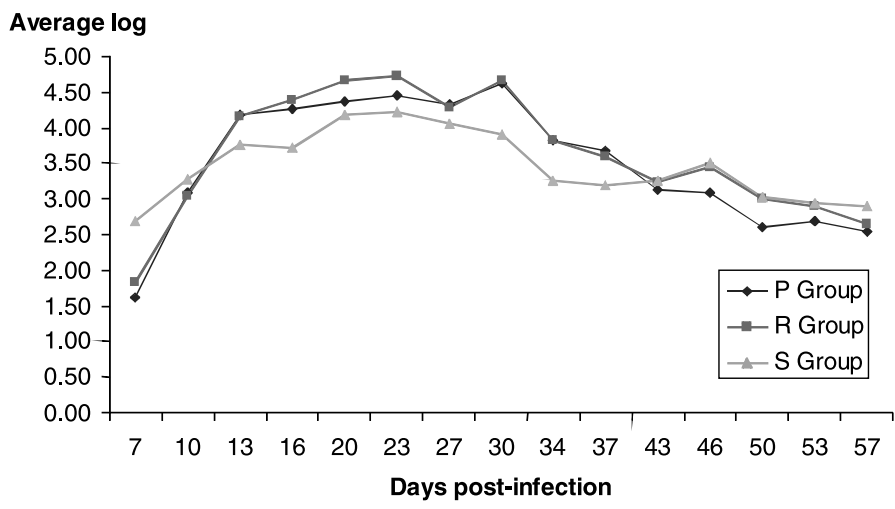

Fig. 1 - Parasitemia curve of blood trypomastigotes $/ 5 \mu \mathrm{L}$ number by $\log$ mean performed during the acute phase of $T$. cruzi QM1 strain infection in mice treated with two different doses of vitamin $\mathrm{C}$ and placebo.

heart muscle than groups $\mathrm{P}(\mathrm{p}=0.0167)$ and $\mathrm{S}(\mathrm{p}=0.0377)$. The presence of amastigote nests was observed in both skeletal muscle and colon tissue.

3. Biochemical analysis: The analysis in Tables 2 and 3 show that in the acute phase there was no statistical difference between groups in any analyzed parameters ( $\mathrm{p}>0.05$ for all comparisons).

\section{DISCUSSION}

According to WEYERS et al. ${ }^{22}$ and RIBEIRO ${ }^{17}$ adequate doses of vitamin $\mathrm{C}$ can act against lipid peroxidation caused by ROS formed naturally or by exogenous compounds in mice, because in electron donating the ascorbate chemically reduces lipid after the peroxidation process. However, the studies of PADAYATTY et al. ${ }^{15}$ and FERREIRA \& MATSUBARA ${ }^{8}$ showed that depending on the vitamin $\mathrm{C}$ dose, it can act as pro-oxidant.

For LEVINE et al. ${ }^{10}$, the plasma levels of vitamin $\mathrm{C}$ plasmatic are maintained when dose fractionation occur at regular intervals of less than $1.5 \mathrm{~h}$. For $\mathrm{BENKE}^{1}$ the plasma concentration of ascorbic acid depends on the dose and administration method, it reaches a saturation plateau within 3 hours of $1 \mathrm{~g}$ vitamin $\mathrm{C}$ having been administered orally and decays linearly within 24 hours. The research of PADAYATTY et $a l .{ }^{16}$ performed on human plasma did not show significant differences when different doses of vitamin $\mathrm{C}$ were administered orally, whereas a
Table 2

Plasma levels of TBARS, total peroxide and ascorbic acid of mice treated with two different doses of vitamin $\mathrm{C}$ and placebo during the acute phase of experimental infection by $T$. cruzi QM1 strain. Variables were expressed as mean \pm standard deviation

\begin{tabular}{lccc}
\hline Variables & $\mathrm{P}$ & $\mathrm{R}$ & $\mathrm{S}$ \\
\hline TBARS $(\mu \mathrm{mol} / \mathrm{mL})$ & $50.1 \pm 7.0$ & $51.9 \pm 11.5$ & $54.7 \pm 6.4$ \\
Total peroxide & $104.5 \pm 35.9$ & $139.9 \pm 50.0$ & $99.9 \pm 28.6$ \\
(Mmol/ $\mathrm{H}_{2} \mathrm{O}_{2}$ equivalent $)$ & & & \\
Ascorbic acid $(\mathrm{mg} / \mathrm{dL})$ & $0.26 \pm 0.05$ & $0.29 \pm 0.14$ & $0.24 \pm 0.05$ \\
\hline
\end{tabular}

$\mathrm{P}=$ animals treated with $10 \mu \mathrm{L}$ of mineral water; $\mathrm{R}=$ animals treated with $\mathrm{D} 60$ dose of vitamin $\mathrm{C}$ equal to $8.6 \times 10^{-4} \mathrm{mg} / \mathrm{g} ; \mathrm{S}=$ animals treated with D500 dose of vitamin $C$ equal to $7.14 \times 10^{-3} \mathrm{mg} / \mathrm{g}$.

Table 3

TBARS, total peroxide and ascorbic acid in mice miocardium treated with two different doses of vitamin $\mathrm{C}$ and placebo during the acute phase of experimental infection by T. cruzi QM1 strain. Variables were expressed as mean \pm standard deviation

\begin{tabular}{lccc}
\hline Variables & $\mathrm{P}$ & $\mathrm{R}$ & $\mathrm{S}$ \\
\hline TBARS $(\mu \mathrm{mol} / \mathrm{g}$ prot) & $301.1 \pm 74.7$ & $298.0 \pm 83.9$ & $359.1 \pm 72.8$ \\
$\begin{array}{l}\text { Total peroxide } \\
\text { (mmol } \mathrm{H}_{2} \mathrm{O}_{2} \text { equivalent/ }\end{array}$ & $528.8 \pm 112.0$ & $637.8 \pm 130.6$ & $538.2 \pm 70.8$ \\
g prot) & & & \\
Ascorbic acid $(\mu \mathrm{g} / \mathrm{g}$ prot) & $5.10 \pm 0.51$ & $5.80 \pm 1.90$ & $6.36 \pm 4.02$ \\
\hline
\end{tabular}

$\mathrm{P}=$ animals treated with $10 \mu \mathrm{L}$ of mineral water; $\mathrm{R}=$ animals treated with $\mathrm{D} 60$ dose of vitamin C equal to $8.6 \times 10^{-4} \mathrm{mg} / \mathrm{g} ; \mathrm{S}=$ animals treated with D500 dose of vitamin C equal to $7.14 \times 10^{-3} \mathrm{mg} / \mathrm{g}$.

significant increase in plasma levels was observed when there was an intravenous application of same dosages.

The researches above could explain the results obtained in this present study where the concentration of vitamin $\mathrm{C}$ in plasma and tissue was similar in all groups, without significant difference between groups $\mathrm{R}$ and $\mathrm{S}$ in comparison with group $\mathrm{P}$, probably because mice supplementation had been performed orally in the morning, in a single daily dose and plasma and tissues collection for this analysis had been done at the end of the $60^{\text {th }}$ day. 
MARIM, R.G.; GUSMÃO, A.S.; CASTANHO, R.E.P.; DEMINICE, R.; THEREZO, A.L.S.; JORDÃO JÚNIOR, A.A. \& MARTINS, L.P.A. - Effects of vitamin C supplementation on acute phase Chagas disease in experimentally infected mice with Trypanosoma cruzi QM1 strain. Rev. Inst. Med. Trop. Sao Paulo, 54(6): 319-23, 2012.

Considering the researches cited earlier and how the animals studied were treated, we may conclude that vitamin $\mathrm{C}$ did not interfere in ROS action and production, as would appear to be the case in the histopathological analysis, which showed a similar amount of inflammation in skeletal muscle and colon tissue in groups $\mathrm{R}$ and $\mathrm{S}$ as in group P. The reduced inflammation and absence of amastigote nests in the heart may be related to a strain characteristic as well as the fact observed by WEN et al. ${ }^{21}$ and DI MEO et al. ${ }^{7}$ who found an improved antioxidant defense system in the hearts of normal mice in comparison with their skeletal muscle and colon tissue. The lower antioxidant efficiency of skeletal muscle may be one explanation for the occurrence of larger damage to this tissue in the acute phase of the illness in this work.

Similarly, the multiplication of the parasite was not affected by different doses of vitamin $\mathrm{C}$, which can be observed by the finding of similar numbers of amastigote nests in the skeletal muscle and colon tissue among the three groups. According to MONTEIRO et al. ${ }^{14}$ the parasite has mechanisms which allow it to benefit from the action of ascorbic acid, it can also use the plasmatic ascorbate present in mammalians to reduce parasite prx and thereby protect itself from peroxides produced by the host, despite that LOGAN et al. ${ }^{11}$ showed that although T. cruzi is not able to capture extracellular vitamin $\mathrm{C}$ to maintain their enzymes prx active, it is able to synthesize vitamin $\mathrm{C}$ from galactono- $\gamma$-lactone and $\mathrm{D}$-arabino- $\gamma$-lactone.

At this stage of the disease it was not observed total peroxides and not decreasing TBARS levels in groups $\mathrm{R}$ and $\mathrm{S}$ compared to $\mathrm{P}$ group, although studies with vitamin E supplementation (800 IU / day) and vitamin C (500 UI/day) had shown TBARS levels reduction in patients with the chronic form of Chagas' disease ${ }^{12}$. The non-animal supplementation with vitamin E in this study may have been the reason why TBARS levels did not reduce in groups $\mathrm{R}$ and $\mathrm{S}$, because vitamins $\mathrm{C}$ and $\mathrm{E}$ act synergistically, blocking lipid peroxidation propagation in cell membranes ${ }^{12}$.

We observed that group S parasitemia was lower than in groups $\mathrm{P}$ and $\mathrm{R}$ from the $10^{\text {th }}$ to the $43^{\text {rd }}$ day, suggesting that the vitamin $\mathrm{C}$ overdose orally administered to this group possibly allowed the immune system to temporarily take contol of parasitic multiplication in the blood, but not in other tissues, indicating that a single daily administration of vitamin $C$ was not enough to maintain the concentration needed to avoid oxidative stress. Moreover, the fact that group S had a higher parasite growth at the end of the acute phase suggests that trypomastigotes can benefit from this higher dosage, as proposed by MONTEIRO et al. ${ }^{14}$ and LOGAN et al. ${ }^{11}$.

\section{RESUMO}

Efeitos da suplementação de vitamina $\mathrm{C}$ sobre a fase aguda da doença de Chagas em camundongos experimentalmente infectados pela cepa QM1 de Trypanosoma cruzi

As alterações teciduais que ocorrem na doença de Chagas estão relacionadas ao grau de estresse oxidativo e à capacidade antioxidante do tecido afetado. Estudos realizados com suplementação de vitamina $\mathrm{C}$ revelaram redução no dano oxidativo causado no hospedeiro pela doença de Chagas, porém outros estudos citam o uso de peroxiredoxinas dependentes de ascorbato pelo T. cruzi para se proteger da ação imune. Com base nessas proposições, trinta camundongos "Swiss" foram infectados com a cepa QM1 de T. cruzi e tratados com duas diferentes doses de vitamina $\mathrm{C}$ para estudar a evolução da parasitemia, alterações histopatológicas e dosagem de biomarcadores de peroxidação lipídica durante a fase aguda da doença de Chagas. Os resultados mostraram que a parasitemia foi maior nos animais que receberam uma superdosagem de vitamina C. Não houve diferenças significativas quanto aos biomarcadores de peroxidação lipídica e houve maior processo inflamatório no miocárdio dos animais tratados com dosagem recomendada. O maior crescimento parasitário ao fim da fase aguda sugere benefício de altas doses de vitamina $\mathrm{C}$ aos tripomastigotas. A suplementação não exerceu influência sobre a produção de radicais livres e o número de ninhos de amastigotas na fase aguda da doença de Chagas.

\section{ACKNOWLEDGEMENTS}

We thank the Foundation for Research Support of São Paulo (FAPESP) for the financial support granted to this project.

\section{CONFLICT OF INTEREST}

All authors declare no conflicts of interest in developing this study.

\section{REFERENCES}

1. Benke KK. Modelling ascorbic acid level in plasma and its dependence on absorbed dose. J Australasian Coll Nutr Environ Med. 1999;18:11-2.

2. Bessey OA. Ascorbic acid. Microchemical methods. In: Vitamin methods. New York Academic Press; 1960. v. 1, p. 303.

3. Brener Z. Therapeutic activity and criterion of cure on mice experimentally infected with Trypanosoma cruzi. Rev Inst Med Trop Sao Paulo. 1962;4:389-96.

4. Champe PC, Harvey RA, Ferrier DR. Bioquímica ilustrada. $3^{\mathrm{a}}$ ed. São Paulo: Artmed; 2006.

5. Costa CM, dos Santos RCC, Lima EA. A simple automated procedure for thiol measurement human and serum samples. J Bras Patol Med Lab. 2006;42:345-50.

6. Coura JR, Dias JCP. Epidemiology, control and surveillance of Chagas' disease: 100 years after its discovery. Mem Inst Oswaldo Cruz. 2009;104(Suppl 1):31-40.

7. Di Meo S, Venditti P, De Leo T. Tissue protection against oxidative stress. Experientia. 1996;52:786-94.

8. Ferreira ALA, Matsubara LS. Radicais livres: conceitos, doenças relacionadas, sistema de defesa e estresse oxidativo. Rev Assoc Med Bras. 1997;43:61-8.

9. Gupta S, Wen JJ, Garg NJ. Oxidative stress in Chagas' disease. Interdiscip Perspect Infect Dis. 2009:8. Article ID 190354. doi:10.1155/2009/190354

10. Levine M, Conry-Cantilena C, Wang Y, Welch RW, Washko PW, Dhariwal KR, et al. Vitamin C pharmacokinetics in healthy volunteers: evidence for a recommended dietary allowance. Proc Natl Acad Sci USA. 1996;93:3704-9.

11. Logan FJ, Taylor MC, Wilkinson SR, Kaur H, Kelly JM. The terminal step in vitamin C biosynthesis in Trypanosoma cruzi is mediated by a FMN-dependent galactonolactone oxidase. Biochem J. 2007;40:419-26.

12. Maçao LB, Wilhelm Filho D, Pedrosa RC, Pereira A, Backes P, Torres MA, et al. Antioxidant therapy attenuates oxidative stress in chronic cardiopathy associated with Chagas' disease. Int J Cardiol. 2007;123:43-9.

13. Martins LPA, Marcili A, Castanho REP, Therezo ALS, Oliveira JCP, Suzuki RB, et al. Rural Triatoma rubrovaria from southern Brazil harbors Trypanosoma cruzi of lineage IIc. Am J Trop Med Hyg. 2008;79:427-34. 
MARIM, R.G.; GUSMÃO, A.S.; CASTANHO, R.E.P.; DEMINICE, R.; THEREZO, A.L.S.; JORDÃO JÚNIOR, A.A. \& MARTINS, L.P.A. - Effects of vitamin C supplementation on acute phase Chagas disease in experimentally infected mice with Trypanosoma cruzi QM1 strain. Rev. Inst. Med. Trop. Sao Paulo, 54(6): 319-23, 2012.

14. Monteiro G, Horta BB, Pimenta DC, Augusto O, Netto LES. Reduction of 1-Cys peroxiredoxins by ascorbate changes the thiol-specific antioxidant paradigm, revealing another function of vitamin C. Proc Natl Acad Sci USA. 2007;104:4886-91.

15. Padayatty SJ, Katz A, Wang Y, Eck P, Kwon O, Lee J-H, et al. Vitamin C as an antioxidant: evolution of its role in disease prevention. J Am Col Nutrition. 2003;22:18-35.

16. Padayatty SJ, Sun H, Wang Y, Riordan HD, Hewitt SM, Katz A, et al. Vitamin C pharmacokinetics: implications for oral and intravenous use. Ann Intern Med. 2004; 140:533-8

17. Ribeiro CM. Efeito do tratamento do benzonidazol e da terapia antioxidante na cardiopatia chagásica crônica. [dissertação]. Florianópolis: Universidade Federal de Santa Catarina; 2009.

18. Silva CRM, Naves MMV. Suplementação de vitaminas na prevenção de câncer. Rev Nutri. 2001;14:135-43
19. Södergren E, Nouroz-Zadeh J; Berglund L, Vessby B. Re-evaluation of ferrous oxidation in xylenol orange assay for the measurement of plasma lipid hydroperoxides. J Biochem Biophys Methods. 1998;37:137-46.

20. Sogayar R. Ética na experimentação animal: consciência e ação. Botucatu: FEPAF; 2006.

21. Wen J-J, Dhiman M, Whorton EB, Garg NJ. Tissue-specific oxidative imbalance and mitochondrial dysfunction during Trypanosoma cruzi infection in mice. Micobes Infect. 2008;10:1201-9.

22. Weyers A, Ugnia LI, Ovando HG, Gorla NB. Antioxidant capacity of vitamin C in mouse liver and kidney tissues. Biocell. 2008;32:27-31.

Received: 1 February 2012

Accepted: 19 June 2012 